\title{
Tingkat pengetahuan dan dukungan keluarga tidak berhubungan dengan kepatuhan menjalani terapi diet penderita diabetes mellitus tipe 2 di Puskesmas Kasihan II Bantul Yogyakarta
}

Knowledge level and family support did not associate with the compliance of diet therapy in the patient $s$ with diabetes mellitus type 2 in Puskesmas Kasihan II Bantul Yogyakarta

Sri Astuti ${ }^{1}$, Yhona Paratmanitya ${ }^{2}$, Wahyuningsih ${ }^{3}$

\begin{abstract}
Background: Diabetes mellitus (DM) can cause various chronic complications on the eyes, kidney, neuronal, and blood vessel. Family support is very important to motivate the patient in performing the treatment of diabetes mellitus or diet. Therefore, knowledge and family support can influence the undergoing treatment or therapy of diabetes mellitus. Having the knowledge, patient can know impact of the disease and influence in the treatment of therapy that must be done. Good knowledge and family supports can improve patient compliance in undergoing diet.

Objectives: To know the association between the knowledge level and family support with compliance in the diet therapy among the patients with diabetes mellitus type 2 in Puskesmas Kasihan II Bantul Yogyakarta. Methods: This was a quantitative descriptive research with cross sectional design. Sampling technique used was quota sampling, where sample were gained in accordance with research criteria of 68 people. Initially, data analysis used was Kolmogorov-Smirnov. Multivariate analysis used was multiple linier regression.

Results: The research showed that the most of respondents had good knowledge level (82.4\%) and also family support of the respondent towards compliance in the diet therapy of DM type 2 (51.5\%). The compliance level of the respondents in the diet therapy of DM type 2 that was in the sufficient category as many as 76.5\%. Knowledge and family support did not relate with compliance in the diet of diabetes mellitus type 2 with p-value consecutively was 0.537 and 0.937. Knowledge level and family support had influence as many $11.5 \%$ toward diet pursuance. Knowledge level influenced more toward diet compliance $(p=0.041)$.

Conclusion: There was no association between knowledge level and family support with compliance in the diet therapy on the patient with diabetes mellitus type 2 in Puskesmas Kasihan II Bantul Yogyakarta.
\end{abstract}

KEYWORDS: knowledge, family support, diabetes mellitus

\begin{abstract}
ABSTRAK
Latar belakang: Diabetes mellitus adalah keadaan hiperglikemi kronik yang disertai berbagai kelainan akibat gangguan hormonal yang menimbulkan berbagai komplikasi kronik pada mata, ginjal, saraf, dan pembuluh darah. Dukungan keluarga sangat penting untuk memotivasi pasien dalam menjalankan pengobatan ataupun diet diabetes mellitus. Oleh karena itu pengetahuan dan dukungan keluarga sangat mempengaruhi dalam menjalankan pengobatan maupun terapi diabetes mellitus, karena dengan pengetahuan yang dimiliki pasien bisa mengetahui tentang penyakitnya, dampak-dampak dari penyakitnya, serta berpengaruh dalam pengobatan maupun terapi yang harus dilakukan, salah satunya adalah diet
\end{abstract}

\footnotetext{
${ }^{1}$ Program Studi S1 IImu Keperawatan STIKES Alma Ata Yogyakarta, Jl. Ringroad Barat Daya 1, Tamantirto, Yogyakarta, e-mail: fahleviiik@gmail.com

${ }^{2}$ Program Studi S1 IImu Gizi STIKES Alma Ata Yogyakarta, Jl. Ringroad Barat Daya 1, Tamantirto, Yogyakarta, e-mail: yhona_nitya@ yahoo.com

${ }^{3}$ Program Studi S1 IImu Keperawatan STIKES Alma Ata Yogyakarta, Jl. Ringroad Barat Daya 1, Tamantirto, Yogyakarta, e-mail: wahyuningsih.psik.aa@gmail.com
} 
diabetes mellitus dan pengetahuan yang baik serta adanya dukungan dari keluarga dapat meninnngkatkan kepatuhan pasien dalam menjalani diet.

Tujuan: Mengetahui hubungan pengetahuan dan dukungan keluarga dalam menjalani terapi diet di Puskemas Kasihan II Bantul Yogyakarta.

Metode: Penelitian ini bersifat deskriptif kuantitatif dengan rancangan cross sectional. Teknik pengambilan sampel yang digunakan yaitu quota sampling dan diperoleh 68 orang. Teknik analisis data yang digunakan yaitu uji Kolmogorov-Smirnov. Analisis multivariat menggunakan regresi linear.

Hasil: Penelitian menunjukkan tingkat pengetahuan responden sebagian besar tergolong baik yaitu sebanyak 82,4\% (56 orang), dukungan keluarga responden terhadap kepatuhan dalam menjalani terapi diet DM tipe 2 yaitu sebagian besar dengan kategori baik sebanyak 51,5\% (35 orang), tingkat kepatuhan responden dalam menjalani terapi diet DM tipe 2 yaitu dalam kategori cukup yaitu sebanyak 76,5\% (52 orang). Untuk pengetahuan dan dukungan keluarga tidak ada hubungan dengan kepatuhan dalam menjalani diet diabetes mellitus tipe 2 dengan menggunakan rumus Kolmogorov-Smirnov didapatkan nilai $p=0,537 ;>0,05$, nilai $p=0,937 ;>0,05$. Koefisien determinasi variabel bebas mempengaruhi variabel terikat sebesar 11,5\% oleh variabel tingkat pengetahuan dan dukungan keluarga.

Kesimpulan: Tidak ada hubungan antara pengetahuan dan dukungan keluarga dengan kepatuhan dalam menjalani diet diabetes mellitus tipe 2 di Puskesmas Kasihan II Bantul Yogyakarta.

KATA KUNCI: pengetahuan, dukungan keluarga, diabetes mellitus

\section{PENDAHULUAN}

Diabetes mellitus (DM) atau kencing manis adalah suatu penyakit dengan peningkatan glukosa darah di atas normal. Pemicu DM adalah faktor keturunan, faktor lingkungan, dan gaya hidup yang tidak sehat, seperti makan berlebihan, berlemak, kurang aktivitas fisik, dan stres (1).

Penyakit diabetes yang banyak diderita di Indonesia adalah DM tipe 2 yang merupakan jenis penyakit diabetes yang mencakup lebih dari $90 \%$ seluruh populasi diabetes. Menurut American Diabetes Association (ADA), faktor risiko DM tipe 2 adalah karena rendahnya kadar kolestrol HDL, yaitu $>250 \mathrm{mg} / \mathrm{dL}(2,82 \mathrm{mmol} / \mathrm{L})(2)$.

DM tipe 2 terjadi karena defek sekresi insulin atau resistensi insulin dan kondisi DM berkembang ketika sekresi insulin sudah tidak adekuat (3).

Menurut Zangeneh dalam Pamungkas, sekresi insulin semakin menurun seiring dengan semakin lama seseorang menderita DM tipe 2 (4).

Menurut beberapa penelitian epidemiologi, prevalensi diabetes di Indonesia berkisar 1,52,3 . Data WHO mengungkapkan, penderita diabetes pada tahun 2000 adalah 135 juta jiwa, dan diperkirakan akan meningkat terus menjadi 366 juta jiwa pada 25 tahun 2025. WHO juga memperkirakan prevalensi penderita DM tipe 2 akan meningkat dari 171 juta jiwa pada tahun 2000 menjadi 366 juta jiwa pada tahun 2030. Beberapa waktu lalu, Internasional Diabetes Federation (IDF) menyatakan bahwa pada tahun 2003 terdapat 194 juta jiwa terkena DM (5).

Depkes RI juga menyatakan, bahwa di Jawa Timur prevalensi penyakit DM sebesar $1,8 \%$ dari seluruh infeksi penyakit yang diderita masyarakat. Tahun 2012, penyakit diabetes millitus di Yogyakarta terdapat 7.434 kasus yang masuk dalam urutan ketiga dan kelima dari distribusi 10 besar penyakit berbasis Puskesmas (6).

Dukungan keluarga sangat penting untuk memotivasi pasien dalam menjalankan pengobatan ataupun diet DM. Oleh karena itu, pengetahuan dan dukungan kerluarga sangat mempengaruhi dalam menjalankan pengobatan maupun terapi DM. Dengan pengetahuan yang dimiliki, pasien bisa mengetahui tentang penyakitnya, dampakdampak dari penyakitnya, serta berpengaruh dalam pengobatan maupun terapi yang harus dilakukan, salah satunya adalah diet DM (7).

Keterlibatan keluarga sejak awal merupakan langkah yang harus ditempuh untuk memberi dukungan pada penderita DM dan akan berdampak positif terhadap kelangsungan pengobatan (1).

Pelayanan pengobatan DM tipe $2 \mathrm{di}$ Puskesmas Kasihan II Bantul pada tahun 2012 
sebanyak 1.431 pasien, sedangkan pada tahun 2013 terdapat 1.436 pasien. Berdasarkan studi pendahuluan di Puskesmas Kasihan II Bantul pada tanggal 11 Februari 2014 melalui wawancara terhadap responden, diketahui bahwa terdapat 3 orang $(60 \%)$ pasien kurang mengetahui definisi dan pola makan yang dianjurkan untuk penderita DM, sementara 2 orang ( $40 \%)$ lainnya memiliki pengetahuan yang cukup baik.

Berdasarkan uraian di atas dilakukan penelitian dengan judul "Hubungan Antara Tingkat Pengetahuan dan Dukungan Keluarga dengan Kepatuhan dalam Menjalani Terapi Diet pada Penderita DM Tipe 2 di Puskesmas Kasihan II Bantul Yogyakarta".

\section{BAHAN DAN METODE}

Jenis penelitian ini adalah deskriptif kuantitatif dengan rancangan cross sectional. Penelitian telah dilaksanakan di Puskesmas Kasihan II Bantul Yogyakarta pada Bulan Juni 2014. Populasi adalah seluruh pasien DM tipe 2 yang melakukan pengobatan di Puskesmas Kasihan II Bantul. Kriteria inklusi yaitu pasien dengan DM tipe 2, berada di lokasi saat penelitian, dan bersedia menjadi responden dengan (dibuktikan melalui pengisian informed consent). Kriteria eksklusi yaitu pasien DM yang tidak bisa membaca dan menulis. Teknik pengambilan sampel dengan quota sampling dan didapatkan sampel sebanyak 68 pasien. Variabel bebas adalah tingkat pengetahuan dan dukungan keluarga, sementara variabel terikat adalah kepatuhan diet DM.

Data penelitian dikumpulkan dengan menggunakan kuesioner yang terdiri dari 56 pertanyaan meliputi karakteristik, pengetahuan, dan dukungan keluarga. Kriteria penilaian pengetahuan dengan ketentuan (baik: skor $75-100 \%$, kurang: skor $56-74 \%$, kurang: skor $<56 \%$ ). Kriteria penilaian dukungan keluarga dengan ketentuan (baik: skor $\geq 47$, cukup: $33-47$, kurang: <33). Kuesioner sudah diujikan pada 30 orang pasien DM yang mempunyai karakteristik yang hampir sama dengan responden di Puskesmas Sedayu dan didapatkan hasil yang valid dan reliabel.
Data hasil penelitian dianalisis dengan analisis univariat dengan tabel frekuensi dan uji bivariat dengan uji chi-square diganti dengan uji Kolmogorov-Smirnov karena tidak memenuhi syarat. Uji multivariat menggunakan regresi linear.

\section{HASIL}

\section{Distribusi frekuensi berdasarkan karakteristik responden}

Tabel 1 menunjukkan bahwa responden paling banyak berjenis kelamin perempuan, yaitu $67,6 \%$ (46 orang), berumur $40-60$ tahun yaitu $52,9 \%$ (36 orang), dan memiliki tingkat pendidikan terakhir sekolah tamat SD yaitu sebanyak $38,2 \%$ (26 orang), dan memiliki pekerjaan ibu rumah tangga (IRT) sebanyak $51,5 \%$ (35 orang).

Tabel 1. Distribusi frekuensi karakteristik responden penderita DM di Puskesmas Kasihan II Bantul Yogyakarta tahun 2014 (n=68)

\begin{tabular}{lcc}
\hline $\begin{array}{c}\text { Karakteristik } \\
\text { responden }\end{array}$ & $\mathbf{f}(\mathbf{n})$ & $\begin{array}{c}\text { Persentase } \\
\mathbf{( \% )}\end{array}$ \\
\hline $\begin{array}{l}\text { Jenis kelamin } \\
\text { Laki-laki }\end{array}$ & 22 & 32,4 \\
Perempuan & 46 & 67,6 \\
Umur & & \\
$<40$ tahun & 1 & 1,5 \\
$40-60$ tahun & 36 & 52,9 \\
$61-80$ tahun & 29 & 42,6 \\
$>80$ tahun & 2 & 2,9 \\
Pendidikan & & \\
Tidak tamat SD & 11 & 16,2 \\
Tamat SD & 26 & 38,2 \\
Tamat SMP & 24 & 35,3 \\
Tamat SMA & 7 & 10,3 \\
Pekerjaan & & \\
Tidak bekerja & 2 & 2,9 \\
IRT & 35 & 51,5 \\
Wiraswasta & 1 & 1,5 \\
Buruh & 13 & 19,1 \\
Petani & 17 & 25 \\
\hline
\end{tabular}

\section{Distribusi frekuensi tingkat pengetahuan responden tentang DM tipe 2}

Berdasarkan Tabel 2 dapat dilihat bahwa ratarata tingkat pengetahuan responden tergolong baik yaitu sebanyak $82,4 \%$ (56 orang), dan paling sedikit dengan kategori cukup yaitu $11,8 \%$ (8 orang). 
Tabel 2. Distribusi frekuensi tingkat pengetahuan penderita DM di Puskesmas Kasihan II Bantul Yogyakarta tahun 2014

\begin{tabular}{lcc}
\hline Tingkat pengetahuan & $\mathbf{f}(\mathbf{n})$ & Persentase (\%) \\
\hline Baik & 56 & 82,4 \\
Cukup & 4 & 5,9 \\
Kurang & 8 & 11,8 \\
Total & 68 & 100 \\
\hline
\end{tabular}

\section{Distribusi frekuensi berdasarkan dukungan} keluarga

Berdasarkan Tabel 3 didapatkan dukungan keluarga yang paling banyak yaitu kategori baik sebanyak $51,5 \%$ (35 orang) dan paling sedikit kategori kurang yaitu 10,3\% (7 orang).

Tabel 3. Distribusi dukungan keluarga penderita DM di Puskesmas Kasihan II Bantul Yogyakarta tahun 2014

\begin{tabular}{lcc}
\hline Dukungan keluarga & $\mathbf{f}(\mathbf{n})$ & Persentase (\%) \\
\hline Baik & 35 & 51,5 \\
Cukup & 26 & 38,2 \\
Kurang & 7 & 10,3 \\
Total & 68 & 100 \\
\hline
\end{tabular}

\section{Distribusi frekuensi berdasarkan tingkat kepatuhan}

Berdasarkan Tabel 4, dapat dilihat bahwa tingkat kepatuhan paling banyak yaitu kategori cukup yaitu sebanyak $76,5 \%$ (52 orang), dan paling sedikit yaitu kategori baik sebanyak 2,9\% (2 orang)

Tabel 4. Distribusi frekuensi kepatuhan penderita DM di Puskesmas Kasihan II Bantul Yogyakarta tahun 2014

\begin{tabular}{lcc}
\hline \multicolumn{1}{c}{ Kepatuhan } & $\mathbf{f}(\mathbf{n})$ & Persentase (\%) \\
\hline Baik & 2 & 2,9 \\
Cukup & 52 & 76,5 \\
Kurang & 14 & 20,6 \\
Total & 68 & 100 \\
\hline
\end{tabular}

Tabulasi silang karakteristik responden dengan kepatuhan

Dari Tabel 5 dapat dilihat bahwa persentase kepatuhan baik lebih tinggi pada jenis kelamin perempuan yaitu 4,3\% (2 orang), pada umur $<40$ tahun yaitu $100 \%$ (1 orang), pendidikan SMA yaitu $14,3 \%$, dan pekerjaan IRT yaitu 5,7\% (2 orang).

Tabel 5. Tabulasi silang karakteristik dengan kepatuhan penderita DM di Puskesmas Kasihan II Bantul Yogyakarta tahun 2014

\begin{tabular}{|c|c|c|c|c|c|c|c|c|}
\hline \multirow{2}{*}{ Karakteristik } & \multicolumn{6}{|c|}{ Kepatuhan } & \multicolumn{2}{|c|}{ Total } \\
\hline & Baik & $\%$ & Cukup & $\%$ & Kurang & $\%$ & $n$ & $\%$ \\
\hline \multicolumn{9}{|l|}{ Jenis kelamin } \\
\hline Laki-laki & 0 & $0 \%$ & 20 & $90,9 \%$ & 2 & $9,1 \%$ & 22 & $100 \%$ \\
\hline Perempuan & 2 & $4,3 \%$ & 32 & $64,6 \%$ & 12 & $26,1 \%$ & 46 & $100 \%$ \\
\hline \multicolumn{9}{|l|}{ Umur } \\
\hline$<40$ tahun & 1 & $100 \%$ & 0 & $0 \%$ & $0 \%$ & $0 \%$ & 1 & $100 \%$ \\
\hline 40-60 tahun & 1 & $2,8 \%$ & 26 & $72,2 \%$ & $72,2 \%$ & $25 \%$ & 36 & $100 \%$ \\
\hline $61-80$ tahun & 0 & $0 \%$ & 26 & $89,7 \%$ & $89,7 \%$ & $10,3 \%$ & 29 & $100 \%$ \\
\hline$>80$ tahun & 0 & $0 \%$ & 0 & $0 \%$ & $0 \%$ & $100 \%$ & 2 & $100 \%$ \\
\hline \multicolumn{9}{|l|}{ Pendidikan } \\
\hline Tidak lulus SD & 0 & $0 \%$ & 4 & $36,4 \%$ & 7 & $63,6 \%$ & 11 & $100 \%$ \\
\hline SD & 1 & $3,8 \%$ & 22 & $84,6 \%$ & 3 & $11,5 \%$ & 26 & $100 \%$ \\
\hline SMP & 0 & $0 \%$ & 20 & $83,3 \%$ & 4 & $16,7 \%$ & 24 & $100 \%$ \\
\hline SMA & 1 & $14,3 \%$ & 6 & $85,7 \%$ & 0 & $0 \%$ & 7 & $100 \%$ \\
\hline \multicolumn{9}{|l|}{ Pekerjaan } \\
\hline Petani & 0 & $0 \%$ & 14 & $82,4 \%$ & 3 & $17,6 \%$ & 17 & $100 \%$ \\
\hline Buruh & 0 & $0 \%$ & 11 & $84,6 \%$ & 2 & $15,4 \%$ & 13 & $100 \%$ \\
\hline IRT & 2 & $5,7 \%$ & 25 & $71,4 \%$ & 8 & $22,7 \%$ & 35 & $100 \%$ \\
\hline Tidak bekerja & 0 & $0 \%$ & 1 & $50 \%$ & 1 & $50 \%$ & 2 & $100 \%$ \\
\hline Wiraswasta & 0 & $0 \%$ & 1 & $100 \%$ & 0 & $0 \%$ & 1 & $100 \%$ \\
\hline
\end{tabular}


Tabulasi silang antara tingkat pengetahuan dengan kepatuhan

Untuk kepentingan analisis dilakukan penggabungan kategori yaitu kategori cukup dan kurang dijadikan 1 kategori sehingga hanya terdapat 2 kategori, yaitu baik dan cukup + kurang. Hal ini dilakukan karena ketika dilakukan analisis dengan 3 kategori hasilnya tidak memenuhi syarat uji chisquare.

Berdasarkan Tabel 6 didapatkan bahwa pada responden dengan tingkat pengetahuan baik sebagian besar memiliki tingkat kepatuhan yang baik pula yaitu $3,6 \%$ (2 orang). Berdasarkan hasil analisis yang dilakukan dengan uji KolmogorovSmirnov, didapatkan hasil hitung $p=0,537(p>0,05)$ yang berarti tidak ada hubungan yang signifikan antara tingkat pengetahuan dengan kepatuhan responden dalam menjalani diet DM tipe 2.

\section{Tabulasi silang antara dukungan keluarga dengan kepatuhan}

Persentase kepatuhan baik pada kelompok yang mendapat dukungan keluarga dengan kategori baik tidak jauh berbeda dengan kelompok yang mendapat dukungan keluarga dengan kategori cukup + kurang. Berdasarkan hasil analisis yang dilakukan dengan Kolmogorov-Smirnov, didapatkan hasil hitung $p=0,937(p>0,05)$ yang berarti tidak ada hubungan yang signifikan antara dukungan keluarga dengan kepatuhan responden dalam menjalani diet DM tipe 2.

\section{Analisis regresi linear variabel tingkat pengetahuan dan dukungan keluarga terhadap kepatuhan menjalani terapi diet DM tipe 2}

Berdasarkan hasil analisis regresi linier pada Tabel 8, diketahui nilai $p$ untuk pengetahuan yaitu 0,041, dan dukungan keluarga 0,084, dimana pengetahuan lebih berpengaruh terhadap kepatuhan, karena lebih kecil dari 0,05. Berdasarkan hasil analisis regresi linear, didapatkan hasil untuk Adjusted $R$ square yaitu 0,115 . Hal ini menunjukkan bahwa variabel terikat yaitu kepatuhan responden dalam menjalani terapi diet DM tipe 2 dipengaruhi sebesar $11,5 \%$ oleh variabel tingkat pengetahuan dan dukungan keluarga dan sisanya dipengaruhi

Tabel 6. Tabulasi silang antara tingkat pengetahuan dengan kepatuhan penderita DM di Puskesmas Kasihan II Bantul Yogyakarta tahun 2014

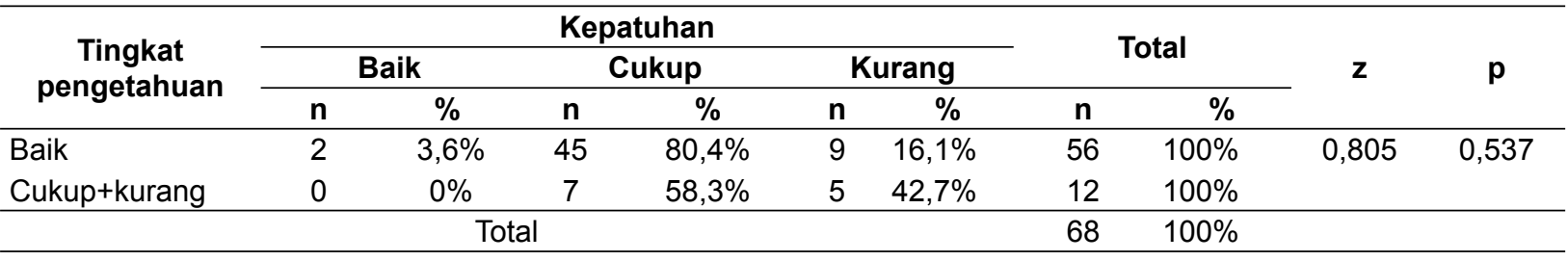

Tabel 7. Tabulasi silang antara dukungan keluarga dengan kepatuhan penderita DM di Puskesmas Kasihan II Bantul Yogyakarta tahun 2014

\begin{tabular}{|c|c|c|c|c|c|c|c|c|c|c|}
\hline \multirow{3}{*}{$\begin{array}{c}\text { Dukungan } \\
\text { Keluarga }\end{array}$} & \multicolumn{6}{|c|}{ Kepatuhan } & \multirow{2}{*}{\multicolumn{2}{|c|}{ Total }} & \multirow{3}{*}{$\mathbf{z}$} & \multirow{3}{*}{$\mathbf{p}$} \\
\hline & \multicolumn{2}{|c|}{ Baik } & \multicolumn{2}{|c|}{ Cukup } & \multicolumn{2}{|c|}{ Kurang } & & & & \\
\hline & $\mathbf{n}$ & $\%$ & $\mathbf{n}$ & $\%$ & $\mathbf{n}$ & $\%$ & $\mathbf{n}$ & $\%$ & & \\
\hline Baik & 1 & $2,9 \%$ & 29 & $82,9 \%$ & 5 & $14,3 \%$ & 35 & $100 \%$ & 0,535 & 0,937 \\
\hline Cukup+kurang & 1 & $3,0 \%$ & 3 & $69,7 \%$ & 9 & $27,3 \%$ & 33 & $100 \%$ & & \\
\hline \multicolumn{7}{|c|}{ Total } & 68 & $100 \%$ & & \\
\hline
\end{tabular}

Tabel 8. Analisis regresi linear variabel tingkat penegetahuan dan dukungan keluarga terhadap kepatuhan dalam menjalani terapi diet DM tipe 2

\begin{tabular}{lcccc}
\hline \multicolumn{1}{c}{ Variabel } & $\boldsymbol{\beta}$ & SE & T & Sig \\
\hline Pengetahuan & 0,171 & 0,149 & 2,086 & 0,041 \\
Dukungan keluarga & 0,143 & 0,082 & 1,757 & 0,084 \\
\hline
\end{tabular}

Adjusted $R$ square: 0,115 
oleh faktor lain yang tidak diteliti dalam penelitian ini. $R$ square berkisar antara 0 sampai 1 , dengan catatan semakin kecil $R$ square, maka semakin lemahhubungan kedua variabel (8).

\section{BAHASAN}

Hubungan antara pengetahuan dan tingkat kepatuhan penderita dalam menjalani terapi diet

Berdasarkan hasil analisis yang dilakukan dengan menggunakan Kolmogorov-Smirnov, didapatkan hasil $p=0,537$ yang berarti tidak ada hubungan antara tingkat pengetahuan dengan kepatuhan responden dalam terapi diet DM tipe 2 $(p>0,05)$.

Hasil penelitian yang tidak signifikan dapat disebabkan faktor lain yaitu lamanya responden dalam menjalani terapi DM. Dengan waktu yang cukup lama, responden akan sering diberikan sosialisasi oleh perawat, khususnya tentang terapi DM dan hal ini dapat mempengaruhi tingkat pengetahuannya. Faktor lain yaitu pendidikan. Dengan pendidikan yang tinggi, maka akan meningkatkan pengetahuan responden tentang DM, selain itu faktor lingkungan dan sosial juga berpengaruh. Dengan adanya dukungan dari keluarga dan teman-teman, kelompok pendukung dapat dibentuk untuk membantu memahami kepatuhan terhadap program pengobatan.

Hasil penelitian ini tidak sejalan dengan penelitian tentang hubungan pengetahuan tentang diet DM dengan kepatuhan pelaksanaan diet pada penderita DM di RSUD dr. H. Moh Anwar Sumenep yang menunjukkan bahwa ada hubungan antara pengetahuan tentang diet DM dengan kepatuhan pelaksanaan diet pada penderita DM dengan nilai signifikan sebesar 0,000 dan nilai korelasi 0,817 (9).

Perilaku baru terutama pada orang dewasa dimulai pada domain kognitif dalam arti subjek tahu terlebih dahulu terhadap stimulus yang berupa materi objek, menimbulkan respon batin dalam bentuk sikap, akhirnya rangsangan yakni objek yang telah diketahui dan disadari sepenuhnya tersebut akan menimbulkan respon lebih jauh lagi yaitu berupa tindakan terhadap stimulus atau objek. Pengetahuan merupakan langkah awal dari seseorang untuk menentukan sikap dan perilakunya, sehingga tingkat pengetahuan akan sangat berpengaruh terhadap penerimaan suatu program (10).

\section{Hubungan antara dukungan keluarga dengan tingkat kepatuhan penderita dalam menjalani terapi diet DM tipe 2}

Berdasarkan hasil analisis yang dilakukan dengan Kolmogorov-Smirnov, didapatkan hasil hitung $p=0,937$. Nilai lebih dari 0,05 berarti tidak ada hubungan yang signifikan antara dukungan keluarga dengan kepatuhan responden dalam menjalani diet DM tipe 2. Hasil ini tidak sejalan dengan penelitian dengan judul Hubungan antara dukungan keluarga keluarga dengan kepatuhan pasien diabetes mellitus dalam melaksanakan program diet di poli penyakit dalam RSUD Cibabat Cimahi. Hasil penelitian tersebut menunjukkan bahwa terdapat hubungan antara dukungan keluarga keluarga dengan kepatuhan pasien dalam melaksanakan program diet (11).

Dukungan keluarga sangat penting untuk memotivasi pasien dalam menjalankan pengobatan ataupun diet DM. Keterlibatan keluarga sejak awal merupakan langkah yang harus ditempuh untuk memberi dukungan pada penderita DM dan akan berdampak positif terhadap kelangsungan pengobatan (1).

\section{Analisis multivariat}

Analisis regresi linier variabel tingkat pengetahuan dan dukungan keluarga terhadap kepatuhan dalam menjalani terapi diet DM tipe 2

Berdasarkan hasil analisis regresi linear, didapatkan nilai pengetahuan $p=0,041$, dan dukungan keluarga 0,084 . Pengetahuan lebih berpengaruh terhadap kepatuhan $(p<0,05)$. Hasil analisis untuk Adjusted $R$ square diperoleh 0,115. Hal ini menunjukkan bahwa variabel terikat yaitu kepatuhan responden dalam menjalani terapi diet DM tipe 2 dipengaruhi sebesar $11,5 \%$ oleh variabel tingkat pengetahuan dan dukungan keluarga, sisanya dipengaruhi oleh faktor lain yang tidak diteliti dalam penelitian ini. Faktor lain yang dimaksud yang dapat mempengaruhi 
kepatuhan antara lain pendidikan, akomodasi, lingkungan dan sosial, serta perubahan model terapi. Pendidikan yaitu suatu kegiatan usaha manusia untuk meningkatkan kepribadian atau proses perubahan perilaku menuju kedewasaan dan penyempurnaan kehidupan manusia dengan jalan membina dan mengembangkan potensi kepribadiannya, yang berupa rohani (cipta, rasa, karsa) dan jasmani (10).

Akomodasi yaitu suatu usaha harus dilakukan untuk memahami ciri kepribadian pasien yang dapat mempengaruhi kepatuhan. Pasien yang mandiri harus dilibatkan secara aktif dalam program pengobatan. Modifikasi faktor lingkungan dan sosial, yaitu membangun dukungan keluarga dari keluarga dan teman-teman sangat penting, kelompok pendukung dapat dibentuk untuk membantu memahami kepatuhan terhadap program pengobatan. Perubahan model terapi program pengobatan dapat dibuat sesederhana mungkin dan pasien terlibat aktif dalam pembuatan program tersebut.

\section{KESIMPULAN DAN SARAN}

Tingkat pengetahuan responden sebagian besar tergolong baik yaitu sebanyak $82,4 \%$ (56 orang). Dukungan keluarga responden terhadap kepatuhan dalam menjalani terapi diet DM tipe 2 yaitu sebagian besar dengan kategori baik sebanyak $51,5 \%$ (35 orang). Tingkat kepatuhan responden dalam menjalani terapi diet DM tipe 2 yaitu dalam kategori cukup yaitu sebanyak $76,5 \%$ (52 orang).

Tidak ada hubungan antara tingkat pengetahuan dengan kepatuhan responden dalam menjalani diet DM tipe 2. Tidak ada hubungan yang signifikan antara dukungan keluarga dengan kepatuhan responden dalam menjalani diet DM tipe 2. Hasil analisis regresi linear menunjukkan bahwa variabel bebas mempengaruhi variabel terikat sebesar $11,5 \%$ oleh variabel tingkat pengetahuan dan dukungan keluarga, dimana sisanya dipengaruhi oleh faktor lain yang tidak diteliti dalam penelitian ini yaitu pendidikan, modifikasi, lingkungan, dan perubahan model terapi. Faktor yang paling berpengaruh yaitu pengetahuan $(p=0,04 ; p<0,05)$.

Pihak puskesmas diharapkan dapat memberikan penyuluhan pendidikan kesehatan kepada masyarakat khususnya tentang diabetes melitus supaya pengetahuan masyarakat dan kesadaran masyarakat meningkat, sehingga dapat memeriksakan kesehatan secara dini. Bagi perawat, diharapkan untuk lebih meningkatkan tugasnya sebagai pendidik, konselor, dan kolaboratif terhadap pasien, khususnya pada pasien yang menderita DM tipe 2. Bagi pasien DM, disarankan untuk melakukan diet DM guna mengatur gula darah agar tetap stabil, serta lebih patuh lagi dalam memeriksakan kesehatan di puskesmas. Selain itu, pasien diharapkan juga dapat mencari informasi yang lebih luas lagi khususnya tentang kepatuhan dalam diet diabetes melitus. Keluarga dapat memberikan dukungan kepada penderita DM serta memberikan motivasi untuk menjalankan terapi diet DM pada pasien. Untuk peneliti lain yang berminat dalam meneliti DM umumnya dan khususnya terhadap diet DM agar mengkaji lebih dalam dan teliti tentang permasalahan yang ada pada pasien DM, sehingga dapat diaplikasikan dalam kehidupan sehari-hari.

\section{RUJUKAN}

1. Dharmono. Diabetes melitus, klasifikasi, diagnosis dan terapi. Jakarta: Gramedia Pustaka Utama; 2007.

2. American Diabetes Association. Diagnosis and classification of diabetes mellitus. Diabetes Care. 2010;33:562-9.

3. Fauci. Harrison's principles of internal medicine. United States America: The McGraw-Hill Companies, Inc; 2008.

4. Pamungkas. Hidup sehat dan bahagia bersama diabetes mellitus. Jakarta: Gramedia Pustaka Utama; 2011.

5. International Diabetes Federation. IDF clinical guidelines task force. Brussels: Global Guideline for Type 2 Diabetes; 2011.

6. Wahdah. Menaklukkan hipertensi dan diabetes. Jakarta: Multi Press; 2011. 
7. Waspadji S. Penatalaksanaan DM terpadu. Jakarta: Universitas Indonesia; 2007.

8. Riduan. Uji statistik univariat dan multivariat. Jakarta: Penerbit Salemba; 2011.

9. Purwanto N. Hubungan pengetahuan tentang diet diabetes mellitus dengan kepatuhan pelaksanaan diet pada penderita diabetes mellitus. J Keperawatan. 2011;1(1).
10. Notoatmodjo S. Pendidikan dan perilaku kesehatan. Jakarta: PT Rineka Cipta; 2003.

11. Pandhit, Hamzah A, Anggina L. Hubungan antara dukungan sosial keluarga dengan kepatuhan pasien diabetes mellitus dalam melaksanakan program diet di Poli Penyakit Dalam RSUD Cibabat Cimahi. J Penelit Kesehat Suara Forikes. 2010;1(Ed. Khusus):1-9. 